\title{
legelivet
}

På disse sidene i Tidsskriftet - legelivet - finner du stoff om legers liv.

Her er det presentasjon av arbeidssteder, nyhetssaker, nye doktorgrader,

nye spesialister og minneord. Alt samlet på ett sted - så du kan følge enda bedre med.

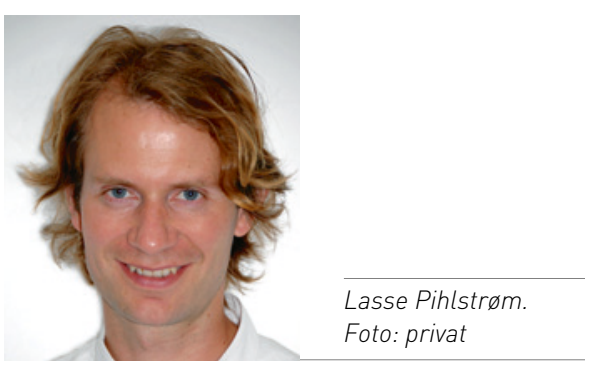

Lasse Pihlstrøm (f. 1980) er stipendiat ved Universitetet i Oslo og lege ved Nevrologisk avdeling, Oslo universitetssykehus.

\section{Visningens under}

Språkfilosofi på klinisk smågruppe. \#denfølelsen.

«Så dere det?! Det er ataksi. La synsinntrykket brenne seg inn i hukommelsen!» Jeg må passe meg så jeg ikke blir for entusiastisk. Hensynet til den velvillige pasienten må komme først, og han har takket ja til undervisning - ikke underholdning.

Jeg smaker på ordet «undervisning». Ganske treffende at det slutter på «-visning». Det er når jeg kan vise, at det virkelig blir bra. Det merkes i hele rommet. Studentene skjerper sansene, lener seg fremover med konsentrerte øyne og kroppsspråk som årvåkne dyr. Nå skjer det noe viktig. Oi, så fristende det er å spille videre på den stemningen, dra til med pompøse formaninger: «Akkurat sånn er rigiditet! Kjenn med deres egne hender, og husk det for resten av livet!» Jeg får nesten frysninger på ryggen.

Hva er så stort med dette? At virkeligheten passer med læreboken? Nei, jeg tror det stikker mye dypere, egentlig helt ned i språkfilosofiens grunnlagsproblemer. Språklig kommunikasjon dominerer all høyere utdanning. I tale og skrift skal kunnskapen komme til oss, ord for ord. Men hvordan kan språket egentlig formidle mening, spør filosofene. Et språk må være noe mer enn et hierarki av definisjoner. Det er gode argumenter for at språket grunnleggende sett ikke kan være meningsbærende uten å forankres i praktisk bruk.

Vinsmaking kan være et treffende eksempel, nettopp fordi mennesker er dårlige til å beskrive lukt og smak. For å komme forbi dette, slik at de kan samtale om vinen, har vinekspertene tatt $\mathrm{i}$ bruk et bredt repertoar av blomstrende karakteristikker av typen «våt hund» eller «petroleum». Og det går knapt an å beskrive eller definere disse smakene nærmere. Vil du bli vinkjenner selv, må du for all del ikke begynne å synse på egenhånd om hvilke karakteristikker som passer best med dine private assosiasjoner. Du må smake og laere hvordan ordene brukes.

På samme måte kan studentene ha lest at «rigiditet» er en økt motstand mot langsomme passive bevegelser, gjerne med et durende, tannhjulsaktig preg. Men før de har kjent det med sine egne hender, vil de alltid være usikre. Slett ikke sjelden vil de tro de kanskje kjenner det: «Det er en jo en uregelmessig motstand der når jeg beveger sakte? Hvorfor er ikke dette rigiditet? Det står jo i boken at...» Det er en interessant øvelse å prøve å gi en logisk, språklig redegjørelse. Men det er like viktig å erkjenne at ikke alt kan forklares til bunns. Dette er rigiditet, dét er det ikke. Det er sånn språket brukes, ordet betyr den følelsen.

Kanskje er alt dette banalt. Vår identitet som leger er jo i stor grad knyttet til ikke-verbal kunnskap, klinisk håndlag og praktiske ferdigheter. Likevel slutter jeg ikke å fascineres av grensesnittet mellom fagspråket og det ubeskrivelige. Det som må kjennes, ses og høres før det kan settes ord på. Det er der undervisningen blir til visningens under.

\section{Lasse Pihlstrøm}

lasse.pihlstrom@medisin.uio.no 